\title{
Vegetative and Environmental Components in a Secondary Riparian Forest in the Southern Plateau of Santa Catarina, Brazil
}

\author{
Lilian Iara Bet Stedille ${ }^{1}$, Juliano Pereira Gomes ${ }^{2}$, \\ Newton Clóvis Freitas da Costa ${ }^{3}$, Paula Iaschitzki Ferreira ${ }^{4}$, Pedro Higuchi ${ }^{1}$, \\ Adelar Mantovani ${ }^{1}$ \\ ${ }^{1}$ Grupo de Pesquisa Uso e Conservação dos Recursos Florestais, Universidade do Estado de Santa Catarina - UDESC, \\ Programa de Pós-graduação em Engenharia Florestal, Lages/SC, Brasil \\ ${ }^{2}$ Grupo de Pesquisa Uso e Conservação dos Recursos Florestais, Universidade do Estado de Santa Catarina - UDESC, \\ Programa de Pós-graduação em Produção Vegetal, Lages/SC, Brasil \\ ${ }^{3}$ Núcleo de Pesquisas em Florestas Tropicais, Universidade Federal de Santa Catarina - UFSC, Programa de Pós-graduação \\ em Recursos Genéticos Vegetais, Florianópolis/SC, Brasil \\ ${ }^{4}$ Departamento Ensino, Pesquisa e Extensão, Instituto Federal de Santa Catarina - IFSC, Lages/SC, Brasil
}

\begin{abstract}
This study investigated the vegetation and environmental variable of fragments at different successional stages in a secondary riparian forest in the municipality of Ponte Alta, Santa Catarina state, Brazil $\left(27^{\circ} 29^{\prime} 00^{\prime \prime} \mathrm{S}\right.$ and $50^{\circ} 17^{\prime} 11^{\prime \prime} \mathrm{W}$, WGS84), aiming to list priority variables for monitoring forest succession in riparian forests. For this, two areas were identified: "Reference" (conserved secondary forest) and "Restoration" (secondary forest under passive restoration). The Principal Component Analysis (PCA) indicated the existence of differences in the arboreal community diversity with lower values for the "Restoration" synthesized by PC1. The ground coverage by Ocellochloa rudis (Nees) Zuloaga \& Morrone (Poaceae) was mainly in places with higher $\mathrm{pH}$ values and ability for effective cation exchange, with no preference of occurrence in either evaluated site. The composition of arboreal diversity was a relevant variable for monitoring passive restoration in this environment.
\end{abstract}

Keywords: araucaria forest, shannon index, Ocellochloa rudis. 


\section{INTRODUCTION}

Monitoring forest succession is a complex process since it involves the successional characteristics of the species and several interactions with biotic and abiotic ecosystem factors. Many ecological processes facilitate successional advancement. However, in some cases thye can act as barriers or strong filters, delaying the balance and services of the system (Rydgren et al., 2013).

The existence of propagule sources, active participation of the soil's seed bank, the seedling bank and the absence of certain species such as superabundant grasses and allochthonous species are highlighted among biotic factors mainly related to the vegetative variables (Martins et al., 2012; Magnago et al., 2012; Rodrigues et al., 2015).

Thus, the remaining floristics of a forest has an important ecological role, creating a structure capable of maintaining environmental services such as the propagule supply (Daronco et al., 2013). The soil seed bank can be determinant in the future of the vegetation of an area, since it is primordial in reestablishing tropical forests, in maintaining and restoring diversity richness after natural or anthropic disturbances, and being mostly composed of pioneer species (Uhl et al., 1988; Matías et al., 2010).

On the other hand, species of late succession naturally have seeds with shorter natural viability, which often present absence or little dormancy germinating soon after dispersion, without remaining in the seed bank (Vale et al., 2009). These species instead remain in the seedling bank comprising the forest's regenerating stratum, awaiting favorable conditions for their development (Chami et al., 2011), and when they are often more vulnerable to abiotic and biotic conditions (Milhomem et al., 2013).

The interspecific competition is one of the main ecological processes involved in forest succession, with emphasis on ruderal species that are cited as ecological filters for the reestablishment of native species (Brancalion et al., 2010), for example, representatives of the Poaceae family, which are superabundant in altered forests (Schmidt \& Longhi-Wagner, 2009).

The canopy cover is another factor that interferes in the successional dynamics since it represents a filter to the energetic flow for the lower sectors of the forest, thereby determining the spatial distribution of species, forest dynamics, and biomass production among other processes (Vilani et al., 2007). Places with little canopy cover favor the presence of species with pioneering characteristics (Martins, 2001).

In addition to the aforementioned factors, the chemical and physical characteristics of the soil should also be considered for monitoring the succession since they form microhabitats that influence the floristic composition (Baylão et al., 2013; Holl, 2013). Besides to biotic and abiotic factors, external factors are also involved in the reestablishment of the communities such as ecological flow, regional species composition and landscape connectivity (Suding \& Hobbs, 2009).

Considering the performance of the different factors involved in forest succession, the complexity of performing "artificial" regeneration of a forest by planting seedlings is highlighted. Therefore, the passive restoration is important as an efficient way of recomposing degraded areas. In order to verify the efficiency of passive restoration in recomposing riparian forests in the Southern Plateau region of Santa Catarina, this study aimed to characterize and investigate some vegetative and environmental variables of preserved secondary forest fragments and those under passive restoration, determining the priority variables for monitoring forest succession.

\section{MATERIAL AND METHODS}

\subsection{Study site}

The study was conducted in areas of riparian forests of the Poço Grande silvicultural farm (Figure 1). The study site was an area of Araucaria Forest (IBGE, 2012) in the municipality of Ponte Alta, Santa Catarina, Brazil (27 $29^{\prime} 00^{\prime \prime} \mathrm{S}$ and $50^{\circ} 17^{\prime} 11^{\prime \prime} \mathrm{W}$, WGS84) under an average altitude of $880 \mathrm{~m}$. The small tributaries and springs that permeated the farm contribute to the Canoas river basin (Santa Catarina, 1997). The relief of the region is classified as wavy/hilly to slightly wavy/hilly relief of hapless cambisol soil with a clay texture (Morales et al., 2012). The climate of the region is classified as humid subtropical mesothermic of "Cfb" type according to Köppen-Geiger, with cool summers and no dry season, frequent severe frosts, average temperature of the hottest months below $22^{\circ} \mathrm{C}$ and annual rainfall ranging from 1600 to $1900 \mathrm{~mm}$ (Alvares et al., 2014). 

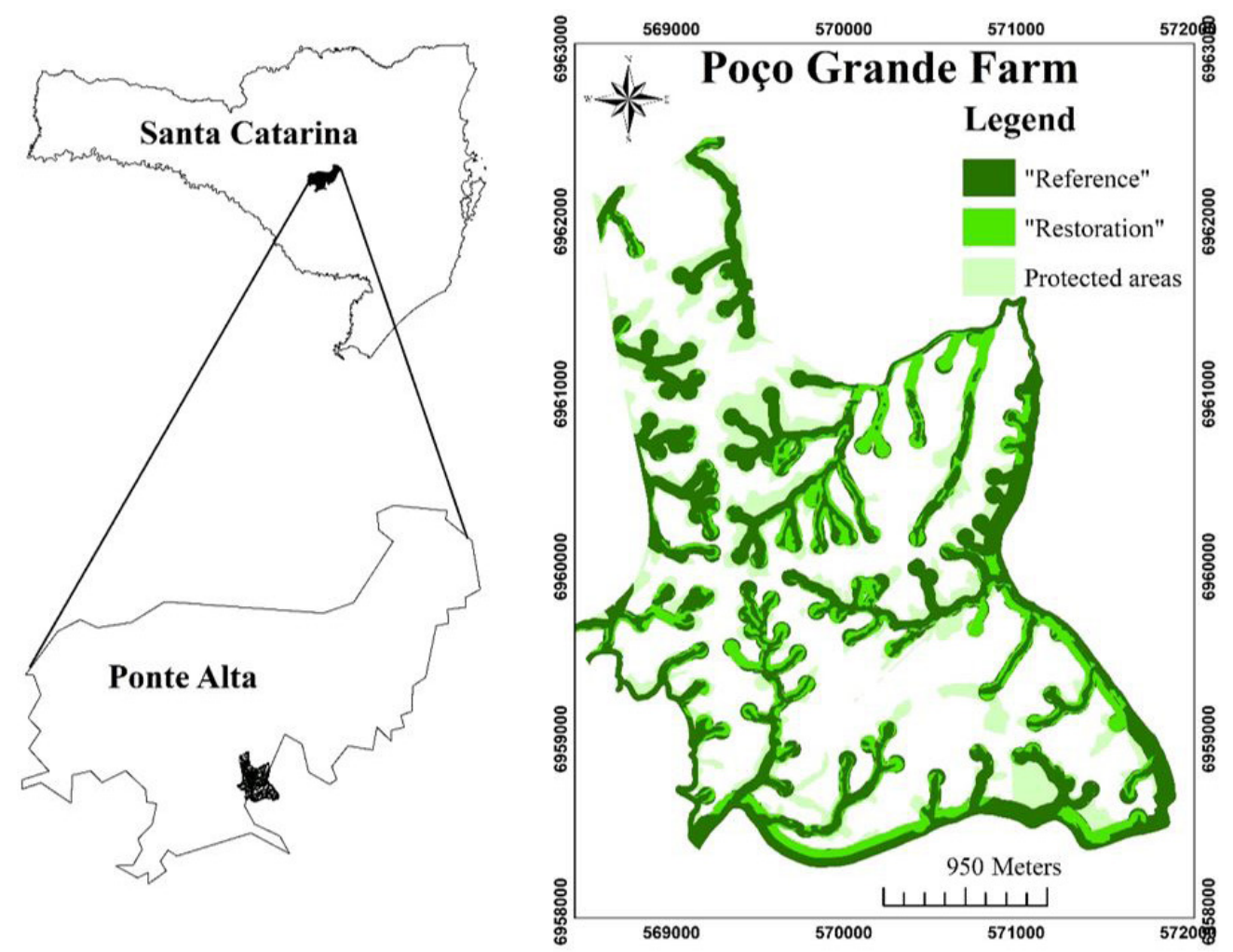

Figure 1. Location of riparian forests (areas "Reference" and "Restoration") and other native areas of the Poço Grande farm, Ponte Alta municipality, Santa Catarina state, Brazil.

Two historically defined sites were used (Ferreira, 2011) (Figure 1): 1) "Reference" - a riparian forest of 176 ha under conserved secondary succession for approximately 40 years without anthropic intervention and with previous selective exploitation in the past; 2) "Restoration" - a secondary riparian forest under passive restoration for 10 years since the removal of forest plantations, seeking environmental adequacy and with a total area of 88 ha. The Southern Plateau of Santa Catarina is characterized by small forest remnants under secondary formation and expressive forestry activity (Rochadelli et al., 2008).

\subsection{Data collection}

For the arboreal stratum sampling, 20 sample units with dimensions of $10 \times 20 \mathrm{~m}\left(200 \mathrm{~m}^{2}\right)$ were randomly allocated, 10 in each area. All individuals with diameter at breast height (DBH) measured at $1.30 \mathrm{~m}$ above ground $\geq 15.7 \mathrm{~cm}$ were identified. For the regenerating stratum sampling, six subunits of $1 \mathrm{~m}^{2}$ were systematically allocated in each $200 \mathrm{~m}^{2}$ sampling unit totaling 60 subunits per area, in which tree individuals with height $\geq 0.1$ and $\leq 1.5 \mathrm{~m}$ were evaluated. The sampling sufficiency of the arboreal and regenerating strata was verified by species accumulation curves, using the permutation method for each area (Efron \& Tibshirani, 1993).

Specialized literature was used and/or specialists were consulted for the species identification. Scientific names were based on the MOBOT Tropicos (MOBOT, 2017). The species belonging to the arboreal stratum were categorized into dispersal syndromes: zoochorous, anemochorous and autochorous, proposed by Van der Pijl (1972), based on propagule observations and citations in scientific works (e.g. Rondon et al., 2001; Giehl et al., 2007), as well as into ecological groups: pioneer, secondary initial, late secondary and climax, according to the descriptions proposed by Budowski (1965) after consulting the literature (Reitz, 1971; Reitz et al., 1978).

Along with a survey of the tree community in each $200 \mathrm{~m}^{2}$ plot, quantification of Merostachys multiramea 
Hack (popularly known in Brazil as taquara) was conducted according to an adaptation of the Fournier index (Fournier, 1974), assigning scores to different intensities of the event "occupation by taquara". According to this method, soil cover measurement of Ocellochloa rudis (Nees) by Zuloaga \& Morrone was also carried out as well as height, performed together with the forest regenerating stratum.

The soil seed bank evaluation was performed with collections in the center of the units $\left(200 \mathrm{~m}^{2}\right)$ using a template $\left(0.3 \mathrm{~m} \times 0.3 \mathrm{~m} \times 0.05 \mathrm{~m}\left(0.0125 \mathrm{~m}^{3}\right)\right)$. The substrate was placed in trays stimulating the seed bank germination under 50\% shading. Germination monitoring was conducted biweekly (every 14 days) over a period of six months by counting and identifying the arboreal species seedlings.

Determining the chemical and physical variables of the soil, there were $100 \mathrm{~g}$ of soil samples systematically collected from four points of the sample unit in the superficial layer (up to $20 \mathrm{~cm}$ ) and then sent to the Soil Analysis Laboratory (Centre of Agroveterinary Sciences, State University of Santa Catarina, Lages, SC, Brazil) according to Tedesco's methodology (Tedesco et al., 1995) for clay determination using the densimeter method. The Canopy cover assessment was carried out according to the methodology proposed by Lemmon (1956), using a convex spherical densitometer placed systematically at two points of the sample unit $\left(200 \mathrm{~m}^{2}\right)$.

\subsection{Data analysis}

After the sufficiency of the sampling strata to estimate floristic diversity, the Shannon index (Ludwig \& Reynolds, 1988), the basal area $\left(\mathrm{m}^{2} . \mathrm{ha}^{-1}\right)$ and percentage of zoochorous and pioneer individuals per sampling unit were calculated. A mean comparison was carried out for all variables obtained in the "Reference" and "Restoration" areas according to the nature of the data (parametric and non-parametric), and then, the Student's t-test and Mann-Whitney U test were used, respectively, with the exception of the diversity index, which was compared by the Hutcheson t-test (Hutcheson, 1970).

The variables were subsequently standardized and submitted to the Principal Component Analysis (PCA), allowing visualization of the dispersion of the sample units as a function of the Principal Component scores (PC) (Kent \& Coker, 1992). A Scree Plot graph was generated to determine the axes to be used in interpreting the results. For the interpretation of the diagram, significant PC scores were considered as those that synthesize a number of variables superior to a model of random distribution (broken-stick). Then, selection of the most important variables in the formation of the PC axis was verified by the loading values (Pearson correlation between the scores of each axis and the variables), where loading values higher than 0.3 were considered as significant in the analysis (Mcgarigal et al., 2000). The Vegan library version 2.3-0 (Oksanen et al., 2015) and R software version 3.2.2 were used for data analysis ( $\mathrm{R}$ Development Core Team, 2015).

\section{RESULTS}

The arboreal stratum of the "Reference" area had 39 species with 33 genera and 18 botanical families. The family with the highest specific richness was Myrtaceae (8 spp.) followed by the Myrcia genus (3 spp.). Regarding this stratum in the "Restoration" area, the samples of 28 species belonging to 25 genera and 15 botanical families were found, in which the Lauraceae family (3 spp.) and the Ilex genus had the highest specific richness (2 spp.) (Table 1 ).

The regenerating stratum composition of the "Reference" area had 24 species belonging to 19 genera and 12 families, where the Myrtaceae family had highest specific richness (7 spp). Fifteen (15) species were found in the "Restoration" area, distributed into 15 genera and 14 families, in which the Lauraceae family ( 2 spp.) had the highest specific richness. Considering the floristic composition of soil seed bank, Mimosa scabrella Benth. was the only tree species sampled in both areas.

Most of the evaluated variables were similar between the areas, with the exception of the average values of zoochorous tree abundance (zoo), Shannon index of trees species (H.arb), tree richness (arbR), available potassium (K) and organic carbon (OC), which were higher for the "Reference" area. Only the percentage of clay (cla) was lower in this area (Table 2).

The interpretation of the Scree plot graph considered the interpretation from PCA up to PC4 to be safe. PC1 was responsible for explaining $27.5 \%$ of the data variation. In this axis, the Shannon index of trees variable (H.arb) is considered significant (loading $=-0.31$ ), with 
Table 1. Arboreal and regenerative floristic components, "Reference" (ref) and "Restoration" (res) areas, presence $(+)$ or absence (-) of the species, followed by ecological grouping (EG) (Where: ${ }^{\text {Pio= }}$ pionner; ${ }^{\text {Sei }}=$ initial secondary; $\mathrm{Sel}=$ late secondary and ${ }^{\mathrm{Cli}}=$ climax) and dispersal syndrome (DS) (Where: ${ }^{\text {Ane }}=$ anemochorous; ${ }^{\text {Aut }}=$ autochorous; $\mathrm{Zoo}^{\mathrm{o}}$ zoochorous) in riparian forests, Ponte Alta, SC, Brazil.

\begin{tabular}{|c|c|c|c|c|c|c|c|}
\hline \multirow{2}{*}{ Families } & \multirow{2}{*}{ Species } & \multicolumn{2}{|c|}{ Arboreal } & \multicolumn{2}{|c|}{ Regenerative } & \multirow{2}{*}{ EG } & \multirow{2}{*}{ DS } \\
\hline & & ref & res & ref & res & & \\
\hline Anacardiaceae & Schinus terebinthifolia Raddi & + & - & - & - & Sei & Zoo \\
\hline \multirow[t]{3}{*}{ Aquifoliaceae } & Ilex microdonta Reissek & - & - & - & + & Sei & Zoo \\
\hline & Ilex paraguariensis A. St.-Hill. & + & + & + & - & Pio & Zoo \\
\hline & Ilex theezans Mart. ex Reissek & + & + & - & - & Sei & zoo \\
\hline Araucariaceae & Araucaria angustifolia (Bertol.) Kuntze & + & - & - & - & Pio & Zoo \\
\hline Arecaceae & Syagrus romanzoffiana (Cham.) Glassman & - & - & + & - & Sei & Zoo \\
\hline \multirow[t]{3}{*}{ Asteraceae } & Piptocarpha angustifolia Dusén ex Malme & + & + & - & + & Pio & Ane \\
\hline & Symphyopappus compressus (Gardner) B.L.Rob. & - & + & - & - & Pio & Ane \\
\hline & Vernonanthura discolor (Spreng.) H.Rob. & + & + & - & - & Pio & Ane \\
\hline Bignoniaceae & Jacaranda puberula Cham. & - & + & - & + & Pio & Aut \\
\hline Cannabaceae & Celtis iguanaea (Jacq.) Sarg. & - & - & - & + & Sei & zoo \\
\hline Clethraceae & Clethra scabra Pers. & + & + & - & + & Pio & Aut \\
\hline Cunoniaceae & Weinmannia paulliniifolia Pohl ex Ser. & - & - & + & - & Sei & Aut \\
\hline Cyatheaceae & Alsophila setosa Kaulf. & + & + & - & - & $\mathrm{Cli}$ & Ane \\
\hline Dicksoniaceae & Dicksonia sellowiana Hook. & + & + & + & + & Cli & Ane \\
\hline Euphorbiaceae & Gymnanthes klotzschiana Müll. Arg. & + & + & - & - & Sei & Aut \\
\hline \multirow[t]{4}{*}{ Fabaceae } & Dalbergia frutescens (Vell.) Britton & + & - & + & + & Sei & Ane \\
\hline & Inga lentiscifolia Benth. & + & - & + & - & Sei & Zoo \\
\hline & Inga virescens Benth. & - & - & + & - & Sei & Zoo \\
\hline & Mimosa scabrella Benth. & + & + & - & - & Pio & Aut \\
\hline \multirow[t]{7}{*}{ Lauraceae } & Cinnamomum amoenum (Nees) Kosterm. & + & - & - & - & Sei & zoo \\
\hline & Cinnamomum glaziovii (Mez) Kosterm & - & + & - & - & $\mathrm{Cli}$ & Zoo \\
\hline & Cryptocarya aschersoniana $\mathrm{Mez}$ & + & - & - & - & Set & zoo \\
\hline & Ocotea puberula (Rich.) Nees & + & + & - & + & Pio & zoo \\
\hline & Ocotea pulchella (Nees \& Mart.) Mez & + & - & - & - & Pio & Zoo \\
\hline & Nectandra lanceolata Nees & + & + & - & - & Sei & Zoo \\
\hline & Nectandra megapotamica (Spreng.) Mez & - & - & - & + & Sei & zoo \\
\hline Meliaceae & Cedrela fissilis Vell. & + & + & - & - & Sei & Ane \\
\hline \multirow[t]{11}{*}{ Myrtaceae } & Calyptranthes concinna DC. & + & - & + & - & Sei & Zoo \\
\hline & Campomanesia rhombea O.Berg & - & - & + & - & Sei & Zoo \\
\hline & Campomanesia xanthocarpa Mart. ex O. Berg & + & - & + & - & Sei & Zoo \\
\hline & Eugenia pluriflora DC. & - & - & + & - & Sei & Zoo \\
\hline & Eugenia subterminalis DC. & + & - & - & - & Sei & Zoo \\
\hline & Myrcia hatschbachii D.Legrand & + & - & + & - & Sei & Zoo \\
\hline & Myrcia palustris DC. & + & - & - & - & Sei & zoo \\
\hline & Myrcia splendens (Sw.) DC. & + & + & - & - & Sei & Zoo \\
\hline & $\begin{array}{c}\text { Myrceugenia miersiana (Gardner) D. Legrand \& } \\
\text { Kausel }\end{array}$ & + & - & + & - & Sei & Zoo \\
\hline & Myrceugenia myrcioides (Cambess.) O.Berg & + & - & - & - & $\mathrm{Cli}$ & Zoo \\
\hline & Myrtaceae sp1 & - & - & + & - & - & $\cdot$ \\
\hline Pinaceae & Pinus taeda $\mathrm{L}$. & - & + & - & - & Pio & Ane \\
\hline \multirow[t]{2}{*}{ Primulaceae } & Myrsine coriacea (Sw.) R.Br. ex Roem. \& Schult. & + & + & + & - & Pio & Zoo \\
\hline & Myrsine lorentziana (Mez) Arechav. & - & - & + & + & Sei & Zoo \\
\hline Proteaceae & Roupala montana Aubl. & - & + & - & - & Sei & Ane \\
\hline Rhamnaceae & Rhaminus sphaerosperma Sw. & - & - & - & + & & \\
\hline Rosaceae & Prunus myrtifolia (L.) Urb. & - & - & - & + & Sei & Zoo \\
\hline
\end{tabular}


Table 1. Continued...

\begin{tabular}{|c|c|c|c|c|c|c|c|}
\hline \multirow{2}{*}{ Families } & \multirow{2}{*}{ Species } & \multicolumn{2}{|c|}{ Arboreal } & \multicolumn{2}{|c|}{ Regenerative } & \multirow{2}{*}{ EG } & \multirow{2}{*}{ DS } \\
\hline & & ref & res & ref & res & & \\
\hline Rutaceae & Zanthoxylum sp. & - & - & - & + & Sei & Zoo \\
\hline \multirow[t]{3}{*}{ Salicaceae } & Banara tomentosa Clos & - & - & + & + & Sel & Zoo \\
\hline & Casearia decandra Jacq. & + & + & + & - & Sei & Zoo \\
\hline & Casearia obliqua Spreng. & + & - & - & - & Sei & Zoo \\
\hline \multirow[t]{3}{*}{ Sapindaceae } & Allophylus edulis (A.St.-Hil. et al.) Hieron. ex Niederl. & + & - & + & - & Sei & Zoo \\
\hline & Cupania vernalis Cambess & + & - & - & - & Sel & Zoo \\
\hline & Matayba elaeagnoides Radlk. & + & + & + & + & Sei & Zoo \\
\hline \multirow[t]{5}{*}{ Solanaceae } & Aureliana fasciculata (Vell.) Sendtn. & + & + & - & - & Pio & Zoo \\
\hline & Cestrum corymbosum Schltdl. & - & + & - & - & Pio & Zoo \\
\hline & Solanum sp1 & - & - & + & - & Pio & Zoo \\
\hline & Solanum pseudoquina A. St.Hill & - & + & - & - & Pio & Zoo \\
\hline & Solanum variabile Mart. & + & + & - & - & Sei & Zoo \\
\hline Styracaceae & Styrax leprosus Hook. \& Arn. & + & - & + & - & Sei & Zoo \\
\hline Symplocaceae & Symplocos tenuifolia Brand & + & + & - & - & Sei & Zoo \\
\hline \multirow[t]{2}{*}{ Undetermined } & Not identified 1 & + & - & - & - & - & - \\
\hline & Not identified 2 & + & - & - & - & $\cdot$ & - \\
\hline Winteraceae & Drimys brasiliensis Miers & + & - & - & - & Sel & Zoo \\
\hline
\end{tabular}

Table 2. Average values of the analyzed variables followed by the mean test, Ponte Alta, SC, Brazil.

\begin{tabular}{|c|c|c|c|c|}
\hline \multirow{2}{*}{ Acronym } & \multirow{2}{*}{ Variable } & Reference & Restoration & \multirow{2}{*}{$p$} \\
\hline & & \multicolumn{2}{|c|}{ Mean \pm standard deviation } & \\
\hline \multicolumn{5}{|c|}{ Non-parametric variables (Mann-Whitney $U$ test) } \\
\hline $\operatorname{arbA}$ & arboreal abundance ( $\mathrm{n}^{\circ}$ ind.) & $22.6 \pm 7.9$ & $20.5 \pm 11.6$ & $0.925^{\mathrm{ns}}$ \\
\hline G & basal area arboreal $\left(\mathrm{m}^{2} / \mathrm{ha}\right)$ & $31.4 \pm 19.5$ & $18.8 \pm 10.3$ & $0.143^{\mathrm{ns}}$ \\
\hline $\mathrm{T}$ & effective cation exchange capacity $\left(\mathrm{cmol} \cdot \mathrm{dm}^{3}\right)^{1}$ & $5.5 \pm 1.6$ & $6.7 \pm 1.8$ & $0.196^{\mathrm{ns}}$ \\
\hline zoo & abundance of zoochorous arboreal (\%) & $63.2 \pm 21.4$ & $26.9 \pm 16.7$ & $0.003^{*}$ \\
\hline \multicolumn{5}{|c|}{ Parametric variables ( $t$-test) } \\
\hline H.arb & $\mathrm{H}^{\prime}$ arboreal (nats.ind $\left.{ }^{-1}\right)$ (Hutcheson t-test) & $1.9 \pm 0.4$ & $1.4 \pm 0.4$ & $<0.001^{*}$ \\
\hline cov & coverage by Ocellochloa rudis (\%) & $30.2 \pm 29.6$ & $41.1 \pm 36.6$ & $0.474^{\mathrm{ns}}$ \\
\hline $\mathrm{pH}$ & potential of hydrogen ${ }^{2}$ & $3.5 \pm 1.1$ & $3.8 \pm 0.3$ & $0.366^{\mathrm{ns}}$ \\
\hline hGra & average height of Ocellochloa rudis (cm) & $23.5 \pm 20.1$ & $40.8 \pm 51.3$ & $0.333^{\mathrm{ns}}$ \\
\hline Mer & occupation by Merostachys multiramea (\%) & $24.5 \pm 24.5$ & $30.3 \pm 36.1$ & $0.682^{\mathrm{ns}}$ \\
\hline $\operatorname{arbR}$ & arboreal richness ( ${ }^{\circ}$ spp.) & $9.3 \pm 2.6$ & $6.3 \pm 2.7$ & $0.022^{*}$ \\
\hline regR & regenerating richness ( $\left.{ }^{\circ} \mathrm{spp}.\right)$ & $3.6 \pm 3.2$ & $2.4 \pm 1.8$ & $0.314^{\mathrm{ns}}$ \\
\hline regA & regenerating abundance ( $\mathrm{n}^{\circ}$ ind.) & $5.6 \pm 6.0$ & $3.1 \pm 2.5$ & $0.239^{\text {ns }}$ \\
\hline can & canopy opening (\%) & $7.4 \pm 4.9$ & $23.0 \pm 30.1$ & $0.139^{\text {ns }}$ \\
\hline $\mathrm{K}$ & available potassium $\left(\mathrm{mg} / \mathrm{dm}^{3}\right)^{3}$ & $0.8 \pm 0.2$ & $0.4 \pm 0.1$ & $<0.001^{\star}$ \\
\hline $\mathrm{Ca}$ & exchangeable calcium $\left(\mathrm{cmol}_{\mathrm{c}} \cdot \mathrm{dm}^{3}\right)^{4}$ & $0.8 \pm 0.8$ & $0.4 \pm 0.3$ & $0.197^{\mathrm{ns}}$ \\
\hline $\mathrm{Mg}$ & exchangeable magnesium $\left(\mathrm{cmol}_{c} \cdot \mathrm{dm}^{3}\right)^{5}$ & $1.0 \pm 2.1$ & $0.2 \pm 0.2$ & $0.246^{\mathrm{ns}}$ \\
\hline $\mathrm{Al}$ & exchangeable aluminum $\left(\mathrm{cmol}_{c} \cdot \mathrm{dm}^{3}\right)^{6}$ & $4.5 \pm 1.6$ & $5.7 \pm 1.9$ & $0.147^{\mathrm{ns}}$ \\
\hline $\mathrm{OC}$ & organic carbon $\left(\mathrm{mg} / \mathrm{dm}^{3}\right)^{7}$ & $1.5 \pm 0.3$ & $1.0 \pm 0.2$ & $0.002^{*}$ \\
\hline SB & saturation by bases $(\%)^{8}$ & $5.7 \pm 3.1$ & $3.4 \pm 2.3$ & $0.070^{\mathrm{ns}}$ \\
\hline $\mathrm{OM}$ & organic matter $(\%)^{9}$ & $1.5 \pm 0.3$ & $1.8 \pm 0.4$ & $0.131^{\mathrm{ns}}$ \\
\hline pio & abundance of pioneer arboreal (\%) & $26.5 \pm 22.8$ & $80.6 \pm 26.1$ & $0.691^{\mathrm{ns}}$ \\
\hline ban A & seed bank abundance ( ${ }^{\circ}$ ind.) & $0.4 \pm 1.0$ & $0.4 \pm 0.7$ & $0.930^{\text {ns }}$ \\
\hline cla & clay $(\%)^{10}$ & $23.1 \pm 3.8$ & $28.7 \pm 5.5$ & $0.010^{*}$ \\
\hline
\end{tabular}

$p=$ probability of the test; $\mathrm{ns}=$ not significant; ${ }^{*}=$ significant for $\alpha: 0.01$. Interpretation of the results according to Tedesco et al. (2004):

${ }^{1}$ high; ${ }^{2}$ very low; ${ }^{3}$ high; ${ }^{4}$ low; ${ }^{5}$ medium (Reference) and low (Restoration); ${ }^{6}$ high; ${ }^{7}$ low; ${ }^{8}$ very low; ${ }^{9}$ low; ${ }^{10}$ class $3(21-40 \%$ of clay). 
the formation of an evident separation between the evaluated areas $(p=0.0009)$. PC2 had $14 \%$ of the total variation of the data, having the following significant variables: $\mathrm{pH}$ (loading $=-0.33)$, cov $($ loading $=-0.34$ ) and $\mathrm{T}$ (loading $=-0.34$ ).

\section{DISCUSSION}

The "Reference" and "Restoration" areas showed distinct floristic compositions, mainly reflected by the variable Shannon index of the tree community (H.arb). Myrtaceae, which presented greater specific richness for both strata of the "Reference" area, can be characterized as an important source of propagules for the "Restoration" area, as the species of this family present zoochory as an associated dispersion syndrome, enabling greater interaction with the fauna (Gressler et al., 2006), and fundamental for advancement of the successional dynamics and an increase in the environmental richness in secondary succession. In the "Restoration" area, the Lauraceae family presented greater specific richness for the arboreal and regenerating strata, contributing to more advanced succession species such as Cinnamomum glaziovii, and with important species in the initial structuring of the Araucaria Forest such as Ocotea puberula, Nectandra lanceolata, and N. megapotamica. Myrtaceae and Lauraceae are commonly described as formers of this phytophysiognomy, and they can be found in the richest families and in several studies (Reitz et al., 1978; Ferreira et al., 2012). Dicksonia sellowiana and Matayba elaeagnoides species are highlighted as they occur in the regenerating and arboreal strata of both areas, being common in both of these ecosystems.

The low representativeness of the species in the composition of the seed bank, confirmed by the restricted presence of Mimosa scabrella in both areas, corroborates the results by Chami et al. (2011), in which the low diversity of the seed bank is described as an intrinsic ecological characteristic of this phytophysiognomy (Araucaria Forest). However, it can also be attributed to the peculiar microhabitat of riparian ecosystems, which often restricts the presence of trees and shrubs in tropical regions prioritizing herb colonization (Araujo et al. 2004). Another relevant factor is the history of the evaluated site, which reflects the richness and historical diversity of the area's seed bank which may be poor where the vegetation has been suppressed or managed for long periods. In this case, plantations of exotic species carried out in the past in the "Restoration" area may negatively influence the seed bank.

Fragments of the "Reference" area were shown as an important source for successional advancement and maintenance of the "Restoration" environments, because the predominance of zoochory associated with greater richness and diversity of arboreal species in the "Reference" area may be able to promote functional connectivity between the two sites, allowing greater genetic flow through fauna action (Liebsch \& Antonio Acra, 2007).

Significant differences among the "Reference" and "Restoration" areas were found for some edaphic variables as being non-relevant according to the interpretations suggested by Tedesco et al. (2004). Thus, "Reference" and "Restoration" areas had high values of available potassium (K), low organic carbon (OC) and a low percentage of class 3 clay (cla), which commonly characterizes dystrophic soils. Clay is a common characteristic for most soils found in the region of the Santa Catarina plateau (Morales et al., 2012).

According to the principal components analysis (PCA), the separation between the plots of the two areas presented by $\mathrm{PC} 1$ shows a clear variation in the floristic-structural composition, predictably occurring along an environmental or successional gradient, as described by Ashton (1989). This variation presented between the areas is of extreme relevance since there are "gains" in floristics and structure according to the time succession in established forests (Liebsch et al., 2007). Such gains in vegetation richness and structure are important aspects for monitoring areas under passive restoration, since the evaluation of variables such as them have been indicated for monitoring the restoration of biodiverse forests, and monitoring the ecological processes involved (Ruiz-Jáen \& Mitchell Aide 2005; Brancalion et al., 2010; Rodrigues et al., 2015).

PC2 demonstrated a significant correlation of cover by Ocellochloa rudis at sites with higher soil $\mathrm{pH}$ and $\mathrm{T}$ values. In this axis, a lack of substitution pattern of the sample units in the evaluated areas was observed and when evaluating the ordering vectors, and a slightly larger association was noticed with some portions of the "Restoration" area (Figure 2). The occupation by Ocellochloa rudis (Poaceae) occurred at sites with higher soil $\mathrm{pH}$ and $\mathrm{T}$ values. However, a gradient with 


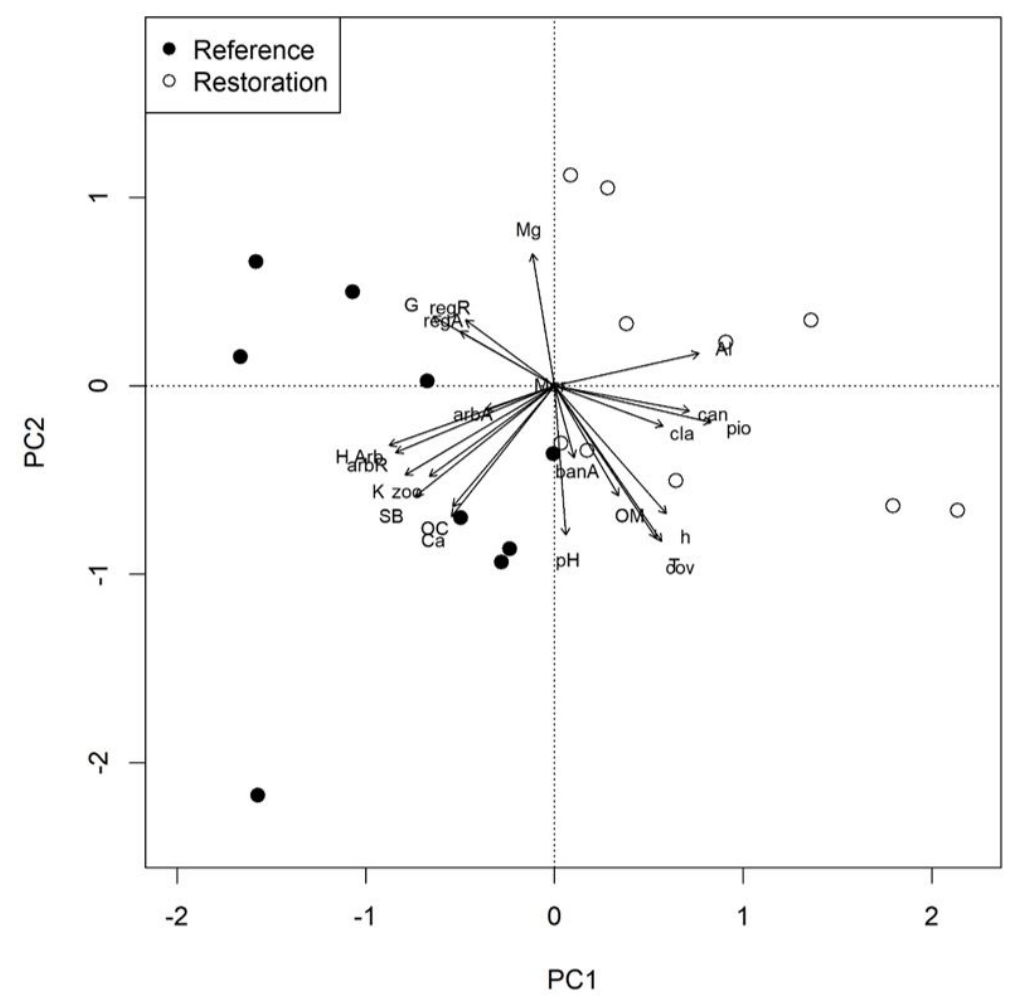

Figure 2. Distribution of plots ("Reference" and "Restoration" areas) and vegetation and environmental variables, survey conducted in the Araucaria Forest, Poço Grande farm, Ponte Alta - SC, Brazil, according to principal components analysis - PCA. Where: PC1= Principal Component 1 and PC2= Principal Component 2.

the presence of the species throughout the sampling is not evident. It is considered that grasses are generally able to form a dense biomass layer, making it difficult for sunlight to reach the soil surface, consequently hindering germination and recruitment of native species of the seed bank (Hughes \& Vitousek, 1993). This physical barrier can also influence propagules from seed rain reaching the soil (Miriti, 1998).

According to the vectors obtained in the PCA analysis (Figure 2), there is a maximum angle formed between the vector coverage by Ocellochloa rudis (cov) with the variables regenerating abundance (arbR) and regenerating richness (regR), suggesting a strong negative association between these variables. Ocellochloa rudis is a native ruderal species, commonly sampled in the vegetation of the Planalto Catarinense region. According to Pastore et al. (2012), they are part of a group of plants that play an important role in ecological succession considering that they are able to assist in establishing secondary vegetation in degraded areas or clearings due to natural or anthropic impacts. For this reason, we can consider that the species showed an association with more fertile and less acidic soils. However, it is not yet known if this relation is formed by the presence of the species in the site, or if the presence of the species is preferentially due to favorable soil characteristics (higher fertility and lower acidity). Nonetheless, this relationship can establish tree species considering a temporal scale, promoting the arrival of more demanding species regarding the micro-habitat. Moreover, this Poaceae is common both inside the forests as well as on its edges (Zuloaga \& Sendulsky, 1988); a fact confirmed in this study as the species did not present an evident relation with canopy opening (can) (Figure 2).

\section{CONCLUSION}

The diversity of the tree community is highlighte among the priority vegetative variables for monitoring areas in passive restoration, followed by the coverage of Ocellochloa rudis (Nees) Zuloaga \& Morrone 
(Poaceae). Regarding the evaluated environmental variables for monitoring passive restoration, they are not representative for the follow-up of successional progression.

\section{ACKNOWLEDGEMENT}

The authors are grateful to the State University of Santa Catarina for granting a master's degree scholarship to the first author, to the Foundation for Research and Innovation of the State of Santa Catarina for the assistance, and to Dr. Rafael Trevisan for the identification of Poaceae Ocellochloa rudis (Nees) Zuloaga \& Morrone.

\section{SUBMISSION STATUS}

Received: 6 oct., 2017

Accepted: 26 oct., 2017

\section{CORRESPONDENCE TO}

\section{Lilian Iara Bet Stedille}

Laboratório de Ecologia Florestal, Programa de Pós-graduação em Engenharia Florestal, Departamento de Engenharia Florestal, Centro de Ciências Agroveterinárias, Universidade do Estado de Santa Catarina - UDESC, Avenida Luiz de Camões, 2090, CEP 88508-640, Lages, SC, Brasil.

e-mail: lilian.stedille@gmail.com

\section{REFERENCES}

Alvares CA, Stape JL, Sentelhas PC, Moraes Gonçalves JL, Sparovek G. Köppen's climate classification map for Brazil. Meteorologische Zeitschrift 2014; 22(6): 711-728. http://dx.doi.org/10.1127/0941-2948/2013/0507.

Araujo MM, Longhi SJ, Barros PLC, Brena DA. Caracterização da chuva de sementes, banco de sementes do solo e plântulas em Floresta Estaciona Decidual ripária Cachoeira do Sul, RS, Brasil. Scientia Forestalis 2004; 66: 128-141.

Ashton PS. Species richess in tropical forests. In: HolmNielsen LB, Nielsen IC, Balslev H, editors. Tropical Forests- botanical dynamics, speciation and diversity. London: Academic Press; 1989.

Baylão HF Jr, Valcarcel R, Nettesheim FC. Fatores do meio físico associados ao estabelecimento de espécies rústicas em ecossistemas perturbados na mata atlântica, Piraí, RJ- Brasil. Ciência Florestal 2013; 23(3): 305-315.
Brancalion PHS, Rodrigues RR, Gandolfi S, Kageyama AG, Gandara LM, Barbosa LM, et al. Instrumentos legais podem contribuir para a restauração de florestas tropicais biodiversas. Árvore 2010; 34(3): 455-470.

Budowski G. Distribution of tropical American rain forest species in the light of sucessional processes. Turrialba 1965; 15(1): 40-42.

Chami LB, Araujo MM, Longhi SJ, Kielse P, Lúcio AD. Mecanismos de regeneração natural em diferentes ambientes de remanescente de Floresta Ombrófila Mista, São Francisco de Paula, RS. Ciência Rural 2011; 41(2): 251-259. http:// dx.doi.org/10.1590/S0103-84782011000200012.

Daronco C, Melo ACG, Durigan G. Ecossistemas em restauração versus ecossistema de referência: estudo de caso da comunidade vegetal de mata ciliar em região de Cerrado, Assis, SP, Brasil. Hoehnea 2013; 40(3): 485-498. http://dx.doi.org/10.1590/S2236-89062013000300008.

Efron B, Tibshirani RJ. An introduction to the bootstrap. New York: Chapman \& Hall; 1993. http://dx.doi. org/10.1007/978-1-4899-4541-9.

Ferreira PI, Paludo GF, Chaves CL, Bortoluzzi RLC, Mantovani A. Florística e fitossociologia arbórea de remanescentes florestais em uma fazenda produtora de Pinus spp. Floresta 2012; 42(4): 783-794. http://dx.doi. org/10.5380/rf.v42i4.21581.

Ferreira PI. Caracterização do componente arbóreo de áreas de preservação permanente em reflorestamentos de espécies exóticas como subsídio para restauração [dissertação]. Lages: Centro de Ciências Agroveterinárias, Universidade do Estado de Santa Catarina; 2011.

Fournier LA. Un método cuantitativo para la medición de características fenológicas en árboles. Turrialba 1974; 24: 422-423.

Giehl ELH, Athayde EA, Budke JC, Gesing JPA, Einsiger SM, Canto-Dorow TS. Espectro e distribuição vertical das estratégias de dispersão de diásporos do componente arbóreo em uma floresta estacional no sul do Brasil. Acta Botanica Brasílica 2007; 21(1): 137-145. http://dx.doi. org/10.1590/S0102-33062007000100013.

Gressler E, Pizo MA, Morellato LPC. Polinização e dispersão de sementes em Myrtaceae do Brasil. Brazilian Journal of Botany 2006; 29(4): 509-530. http://dx.doi.org/10.1590/ S0100-84042006000400002.

Holl KD. Restoring Tropical Forest. Nature Education Knowledge 2013; 4(4): 1-4.

Hughes F, Vitousek PM. Barriers to shrub reestablishment following fire in the seasonal submontane zone of Hawaii. Oecologia 1993; 93(4): 557-563. http://dx.doi.org/10.1007/ BF00328965. PMid:28313825.

Hutcheson K. Test for comparing diversities based on the Shannon Formula. Journal of Theoretical Biology 1970; 29(1): 151-154. http://dx.doi.org/10.1016/00225193(70)90124-4. PMid:5493290. 
Instituto Brasileiro de Geografia e Estatística - IBGE. Manual técnico da vegetação brasileira. 2. ed. Rio de Janeiro: Departamento de Recursos Naturais e Estudos Ambientais; 2012.

Kent M, Coker P. Vegetation description and analysis: A practical approach. Chichester: John Wiley \& Sons; 1992.

Lemmon PA. Spherical densiometer for estimating forest overstory density. Forest Science 1956; 2(1): 314-320.

Liebsch D, Antonio Acra L. Síndromes de dispersão de diásporos de um fragmento de Floresta Ombrófila Mista em Tijucas do Sul, PR. Acadêmica: Ciência Animal 2007; 5(2): 167-175. http://dx.doi.org/10.7213/cienciaanimal. v5i2.9750.

Liebsch D, Goldenberg R, Marques MCC. Florística e estrutura de comunidades vegetais em uma cronossequência de Floresta Atlântica no estado do Paraná, Brasil. Acta Botanica Brasílica 2007; 21(4): 983-992. http://dx.doi. org/10.1590/S0102-33062007000400023.

Ludwig JA, Reynolds JF. Statistical ecology. New York: John Wiley; 1988.

Magnago LFS, Martins SV, Venzke TS, Ivanauskas NM. Os processos e estágios sucessionais da mata atlântica como referência para a restauração florestal. In: Martins SV. Restauração ecológica de ecossistemas degradados. 1. ed. Viçosa: UFV; 2012.

Martins SV, Miranda Neto A, Ribeiro TM. Uma abordagem sobre diversidade e técnicas de restauração ecológica. In: Martins SV, editores. Restauração ecológi ca de ecossistemas degradados. Viçosa: Editora UFV; 2012.

Martins SV. Recuperação de matas ciliares. Viçosa: Aprenda Fácil; 2001.

Matías L, Zamora R, Mendoza I, Hódar JA. Seed dispersal patterns by large frugivorous mammals in a degraded mosaic landscape. Restoration Ecology 2010; 18(5): 619627. http://dx.doi.org/10.1111/j.1526-100X.2008.00475.x.

McGarigal K, Stafford S, Cushman S. Multivariate statistics for wildlife and ecology research. New York: Springer-Verlag; 2000. http://dx.doi.org/10.1007/978-1-4612-1288-1.

Milhomem MEV, Araújo GM, Vale VS. Estrutura do estrato arbóreo e regenerativo de um fragmento de Floresta Estacional Semidecidual em Itumbiara, GO. Ciência Florestal 2013; 23(4): 679-690. http://dx.doi. org/10.5902/1980509812352.

Miriti MN. Regeneração florestal em paisagens abandonadas na Amazônia central: competição, predação e dispersão de sementes. In: Gascon C, Moutinho P., editores. Floresta amazônica: dinâmica, regeneração e manejo. Manaus: INPA; 1998.

Missouri Botanical Garden - MOBOT. Trópicos [online]. Saint Louis: MOBOT; 2017 [cited 2016 Jun 7]. Available from: http://www.tropicos.org/Home.aspx
Morales CAS, Albuquerque JA, Sampietro JA, Morales BP, Almeida JA. Carbono orgânico e atributos químicos do solo em florestas de Pinus taeda. Scientia Plena 2012; 8(4): 1-8.

Oksanen J, Blanchet FG, Kindt R, Legendre P, Minchin PR, O'hara RB, et al. Vegan: Community Ecology Package. Vienna: R package version 3.2.2; 2015

Pastore M, Rodrigues RS, Simão-Bianchini R, Filgueiras TS. Plantas exóticas invasoras na Reserva Biológica do Alto da Serra de Paranapiacaba, Santo André - SP. São Paulo: Instituto de Botânica; 2012.

R Development Core Team. R: A language and environment for statistical computing. Vienna: R Foundation for Statistical Computing versão 3.2.2; 2015.

Reitz PR, Klein RM, Reis A. Projeto Madeira - Santa Catarina. Florianópolis: Lunardelli; 1978.

Reitz PR. Flora Ilustrada Catarinense. Itajaí; Conselho Nacional de Pesquisas; 1971.

Rochadelli R, Mendes RH, Schneider AV, Menon CR, Augustin CR. Expansão florestal na região do planalto serrano catarinense: uma perspectiva a partir do perfil socioeconômico dos proprietários rurais. Floresta 2008; 38(3): 459-464. http://dx.doi.org/10.5380/rf.v38i3.12411.

Rodrigues RR, Gandolfi S, Brancalion PHS. Restauração florestal. São Paulo: Editora Oficina de Textos; 2015.

Rondon RM No, Watzlawick LF, Caldeira MV. Diásporos das espécies arbóreas de um fragmento de Floresta Ombrófila Mista. Ciências Exatas e Naturais 2001; 3(2): 209-216.

Ruiz-Jaen MC, Mitchell Aide T. Restoration success: how is it being measured. Restoration Ecology 2005; 13(3): 569577. http://dx.doi.org/10.1111/j.1526-100X.2005.00072.x.

Rydgren K, Halvorsen R, Auestad I, Hamre N. Ecological design is more important than compensatory mitigation for successful restoration of alpine spoil heaps. Restoration Ecology 2013;21(1): 17-25. http://dx.doi.org/10.1111/j.1526100X.2012.00865.X.

Santa Catarina. Secretaria de Estado e Desenvolvimento Urbano e Meio Ambiente. Bacias Hidrográficas de Santa Catarina: diagnóstico geral. Florianópolis: SDM; 1997.

Schmidt R, Longhi-Wagner HM. A tribo Bambusae (Poaceae, Bambusoideae) no Rio Grande do Sul, Brasil. Revista Brasileira de Biociências 2009; 7(1): 71-128.

Suding KN, Hobbs RJ. Threshold models in restoration and conservation: A developing framework. Trends in Ecology \& Evolution 2009; 24(5): 271-279. http://dx.doi. org/10.1016/j.tree.2008.11.012. PMid:19269057.

Tedesco MJ, Gianello C, Anghinoni I, Bissani CA, Camargo FAO, Wiethölter S. (org.) Manual de adubação e de calagem para os estados do Rio Grande do Sul e de Santa Catarina. Porto Alegre: Sociedade Brasileira de Ciência do Solo; 2004. 
Tedesco MJ, Gianello C, Bissani CA, Bohnen H, Volkweiss SJ. Análise de solo, plantas e outros materiais. 2. ed. Porto Alegre: UFRGS, Departamento de Solos; 1995.

Uhl C, Buschbacher R, Serrão A. Abandoned pastures in Eastern Amazônia: 1- patterns of plant succession. Journal of Ecology 1988; 75(3): 663-681. http://dx.doi. org/10.2307/2260566.

Vale VS, Schiavini I, Lopes SF, Dias Neto OC, Oliveira AP, Gusson AE. Composição florística e estrutura do componente arbóreo em um remanescente primário de Floresta Estacional Semidecidual em Araguari, Minas Gerais, Brasil. Hoehnea 2009; 36(3): 417-429. http://dx.doi. org/10.1590/S2236-89062009000300003.
Van Der Pijl L. Principles of dispersal in higher plants. Berlim: Springer; 1972. http://dx.doi.org/10.1007/9783-642-96108-3.

Vilani MT, Sanches L, Costa MH, Gaio DC, Nogueira J S. Estimativa da absortância da radiação fotossinteticamente ativa de uma vegetação de transição floresta Amazônica-cerrado por três métodos. Revista Brasileira de Agrometeorologia 2007; 15(3): 289-298.

Zuloaga FO, Sendulsky TA. Revision of Panicum subgenus Phanopyrum section Stolonifera (Poaceae: Paniceae). Annals of the Missouri Botanical Garden 1988; 75(2): 420-455. http://dx.doi.org/10.2307/2399432. 